\title{
A new alien bryozoan Celleporaria brunnea (Hincks, 1884) in the Aegean Sea (eastern Mediterranean)
}

\author{
FERAH KOÇAK \\ Dokuz Eylül University, Institute of Marine Sciences and Technology, 35340, Inciraltı-Izmir, Turkey. \\ E-mail: ferah.kocak@deu.edu.tr
}

\begin{abstract}
SUMMARY: The ascophoran Bryozoa Celleporaria brunnea, a new record for the Mediterranean Sea, was found on Mytilus galloprovincialis collected in the inner part of Izmir Bay (Aegean Sea, Turkey) in September 2004. The species was previously reported from the Pacific coast of the United States. Its occurrence in the polluted inner part of Izmir Bay, near Alsancak Harbour, suggests that it has been newly introduced to the area, possibly via ship hulls. The morphological, ecological and zoogeographical characteristics of the species are given and discussed.
\end{abstract}

Keywords: introduced species, Celleporaria brunnea, Izmir Bay, Aegean Sea, eastern Mediterranean, Turkey.

RESUMEN: UN NUEVO BRIOZOO INTRODUCIDO CELLEPORARIA BRUNNEA (HINCKS, 1884) EN EL MAR EGEO (MEDITERRÁNEO ORIENTAL). - El briozoo ascoforo Celleporaria brunnea, especie nueva para el mar Mediterráneo, se encontró en Mytilus galloprovincialis recolectado en la parte interna de la bahía de Izmir (mar Egeo, Turquía) en septiembre de 2004. La especie se había reportado previamente en la costa del Pacífico de Estados Unidos. Su aparición en la parte interna contaminada de la bahía de Izmir, cerca del Puerto de Alsancak, sugiere que ha sido introducida en el área, posiblemente a través de los cascos de los barcos. En este trabajo se presentan y discuten las características morfológicas, ecológicas y zoogeográficas de la especie.

Palabras clave: especie introducida, Celleporaria brunnea, bahía de Izmir, mar Egeo, Mediterráneo oriental, Turquía.

\section{INTRODUCTION}

Non-induced movements of marine species between different biogeographical regions are an increasing trend worldwide (Por, 1971; Leppakoski, 1991; Gollasch, 2002; Paavola et al., 2005). The Mediterranean Sea is one of the major recipients of alien species (Galil, 2000; Galil and Zenetos, 2002). The main vectors of introduction of alien species in the region are Lessepsian migration, shipping and aquaculture (Cognetti and Maltagliati, 2000). The opening of the Suez Canal in 1869 resulted in the migration of Red Sea species to the eastern Mediterranean basin (Por, 1971; Zibrowius, 1991).
According to Streftaris et al. (2005), Erythrean species entering the Mediterranean using the Suez Canal constitute a significant part (52\%) of the exotic fauna and flora in the Mediterranean Sea, and within this zoobenthic organisms are the most important taxa, accounting for $70 \%$ of the aliens.

Particular conditions within ports, including eutrophication and pollution, may facilitate the establishment of alien species (Minchin and Gollasch, 2003; Galil, 2000). High food availability in ports may also facilitate the settlement of alien species (Koçak et al., 1993). Most invasive species have an r-selected life history and their capacity to tolerate environmental stress allows them to become 
established easily in new non-native habitats and to be competitively dominant over native species (Byers, 2002; McMahon, 2002; Ambrogi and Savini, 2003). In brackish waters, low species richness provides less competition and unoccupied niches for establishing species (Leppakoski and Olenin, 2000; Paavola, et al., 2005).

Bryozoans are benthic colonial invertebrates in marine hard-bottom environments and some of them occur in hull fouling communities (Lewis et al., 2004; Carlton, 1985; Gollasch, 2002). Several studies have been conducted on the bryozoan species collected from the Levantine Sea including the coasts of Israel (Powell, 1969a; Brood, 1980; d'Hondt, 1988), Lebanon (Bitar and Bitar, 2001), Turkey (Ünsal and d'Hondt, 1979) and Cyprus (Koçak et al., 2002).

The present study provides a new distant locality for $C$. brunnea, and additional information about its morphological and ecological characters.

\section{MATERIALS AND METHODS}

The present results are part of a study carried out seasonally from July 2003 to-September 2004 at four hard-bottom stations in Izmir Bay (Aegean Sea) (Fig. 1). At each station, three samples were taken at $0.2 \mathrm{~m}$ depth by scraping off an area of $400 \mathrm{~cm}^{2}$ using a spatula. Material was fixed in $4 \%$ formaldehyde in the field and washed through a sieve with $0.5 \mathrm{~mm}$ mesh size in the laboratory. Afterwards, samples were sorted under a stereomicroscope and preserved in $70 \%$ ethanol. At all stations, bryozoan species

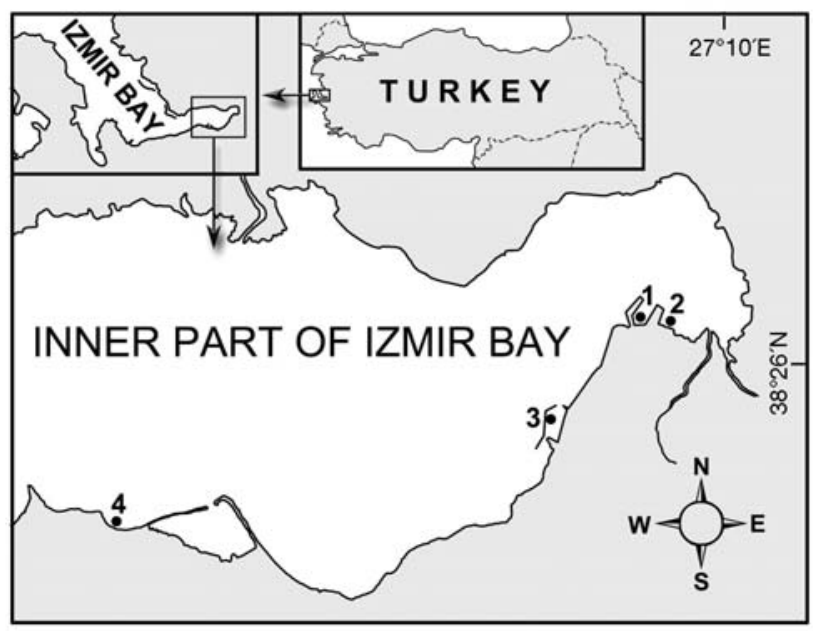

FIG. 1. - Map of the investigated area with the location of stations. Celleporaria brunnea was collected only at Station 4. were determined at species level. In September 2004, a new alien bryozoan species, Celleporaria brunnea, was found on Mytilus galloprovincialis species at Station 4 near Çakalburnu Lagoon. Measurements of some parts of zooids were made using ocular micrometer. The autozooid morphology was illustrated by scanning electron microscope (SEM). The specimens are deposited at the Museum of the Faculty of Fisheries, Ege University (ESFM: Ege Üniversitesi Su Ürünleri Fakültesi Müzesi).

\section{RESULTS AND DISCUSSION}

\section{Order CHEILOSTOMATIDA Busk, 1852 \\ Suborder AsCOPHORINA Levinsen, 1909 \\ Family CELlEPORARIIDAE Harmer, 1957 \\ Genus Celleporaria Lamouroux, 1816 \\ Celleporaria brunnea (Hincks, 1884)}

(Figs. 2A-D)

Holoporella brunnea Hastings, 1929:731-732, pl. 16, Figs. 108110; Osburn, 1952: 496-497, pl. 62, Figs. 10-12; Soule, 1961: 5556; Soule and Soule, 1964: 38-40, Figs. 13-14.

Celleporaria brunnea Soule et al., 1997: 267-268, pl. 101, A-C.

Material examined. Aegean Sea (Izmir Bay): Station 4 $\left(38^{\circ} 24.780^{\prime} \mathrm{N}-27^{\circ} 02.020^{\prime} \mathrm{E}\right)$, Inciraltý, ESFM-BRY/04-1, $0.2 \mathrm{~m}, 14$ September 2004 (temperature $21^{\circ} \mathrm{C}$, salinity $38.6 \mathrm{psu}$, dissolved oxygen concentration $7.6 \mathrm{mg} / \mathrm{l}$ ), 18 colonies on Mytilus galloprovincialis, serpulid and spirorbids.

Description. Encrusting colony with irregular autozooids (Fig. 2A). Mean autozoecial length, 442 $\mu \mathrm{m}$, mean width $277 \mu \mathrm{m}$. Zoaria white to gray in colour. Opercula, sclerite of mandibles, base of spines dark brown. Frontal shield calcification smooth or finely granular with few small indistinct marginal pores. Boundaries distinct at growing edge. Primary orifice wider than long, with proximal concave border. Mean length of orifice $131 \mu \mathrm{m}$, mean width $154 \mu \mathrm{m}$ (Fig. 2B). Distal border of primary orifice rounded, sometimes bearing a pair of tall, stout, widely spaced distal oral spines or more rarely three spines close to each other. Peristome more developed along proximal edge of orifice. A single, proximal suboral avicularium present on midline of orifice border, perpendicular to frontal plane. Rostrum oval, rounded with fine denticulations on distal rim (Fig. 2C). Columella absent, sclerites of mandible semieliptical, dark brown in colour. Vicarious avicularia abundant, measuring $328 \mu \mathrm{m}$ long, $130 \mu \mathrm{m}$ wide (Table 1). Rostrum parallel-sided, subspatulate, enlarged slightly through 

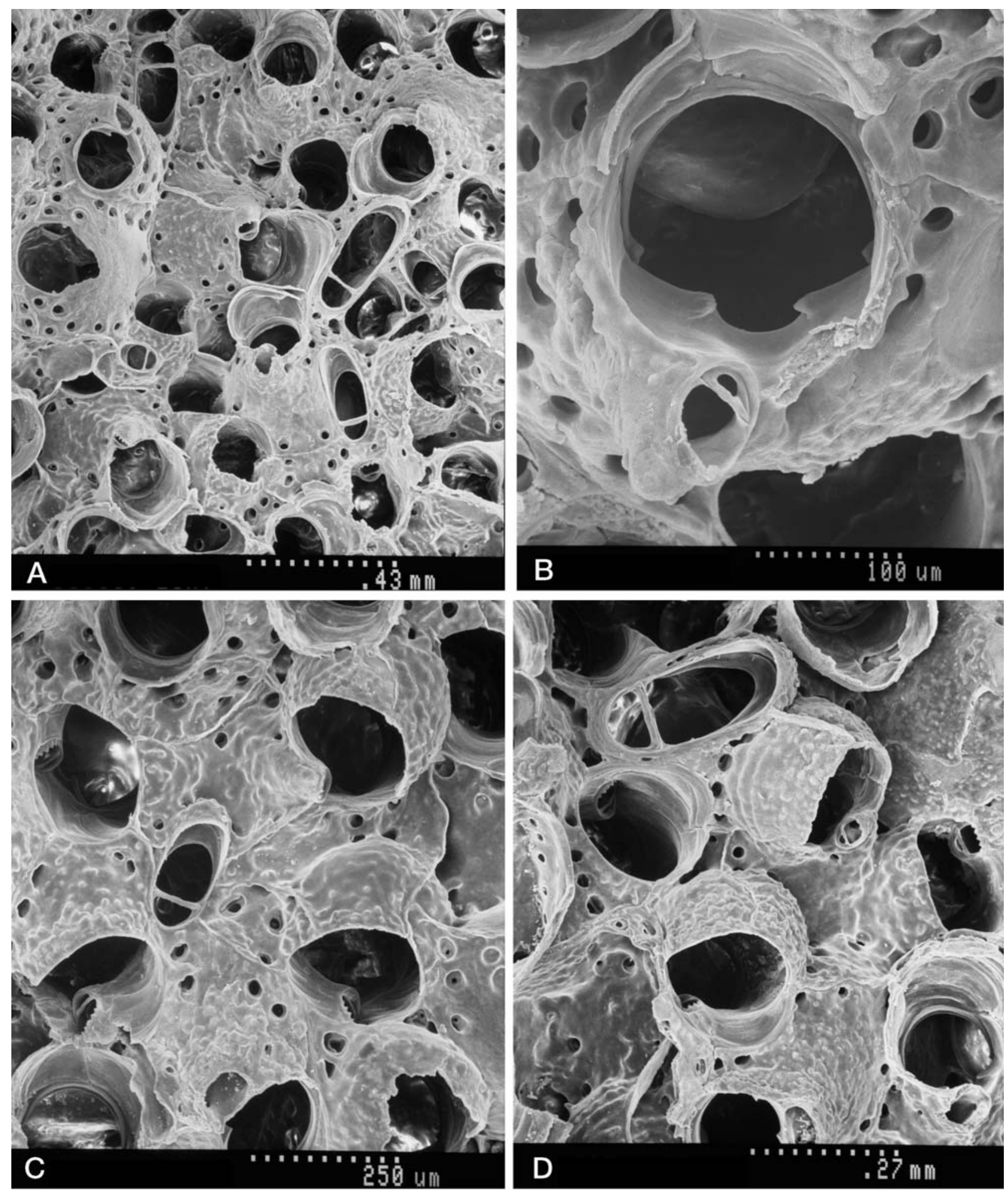

FIG. 2. - Celleporaria brunnea. A. General view of a colony, B. Primary orifice, C. Suboral avicularium with fine denticulations on distal rim, D. Ovicellated colony with interzooidal avicularia.

distal part. Sclerites of mandible spade-shaped with short handle, dark brown in colour. Crossbar slender without columella. Ovicell widely open, finely granular, unpunctured (Fig. 2D).
Associated bryozoans species. Celleporaria brunnea was the most frequent bryozoan species at Station 4 in September 2004 with other bryozoan species: Bowerbankia gracilis Leidy, 1855, 
TABLE 1. - Measurements $(\mu \mathrm{m})$ of Celleporaria brunnea.

\begin{tabular}{|c|c|c|c|c|c|}
\hline & $\mathrm{N}$ & Mean & Minimum & Maximum & SD \\
\hline Autozooid length & 20 & 442 & 340 & 540 & 55 \\
\hline Autozooid width & 20 & 277 & 240 & 340 & 24 \\
\hline Primary orifice height & 12 & 131 & 110 & 150 & 12 \\
\hline Primary orifice width & 12 & 154 & 140 & 170 & 9 \\
\hline Vicarious avicularia length & 12 & 328 & 240 & 400 & 59 \\
\hline Vicarious avicularia width & 12 & 130 & 120 & 140 & 10 \\
\hline
\end{tabular}

$\mathrm{N}$, number; SD, Standard deviation

Cryptosula pallasiana (Moll) and Schizoporella unicornis (Johston in Wood). Bowerbankia gracilis and C. pallasiana, which are known to be widespread fouling species in ports and estuaries, were found on Mytilus galloprovincialis, barnacles and serpulid polychaetes. Only a colony of Schizoporella unicornis was found on M. galloprovincialis at Station 4. Among the species, $B$. gracilis was considered as an alien species in New Zealand and the United States (Carlton, 1989; Cranfield et al., 1998), C.pallasiana and S. unicornis in Australia (Pollard and Pethebridge, 2002).

Distribution. Celleporaria brunnea is one of the most common species in California and Baja California waters (Soule and Soule, 1964). The distribution of the species extends from British Colombia southward to Ecuador (Soule et al., 1997). This species was found in the vicinity of the Panama Canal (Hastings, 1929). It was also recorded from Hawaii, where it may have been transported via hull fouling (Godwin, 2003).

The genus Celleporaria includes 72 recent species worldwide. Among them, three species have been previously reported from the Mediterranean Sea: Celleporaria aperta (Hincks, 1882), Celleporaria fusca (Busk, 1854) and Celleporaria pilaefera (Canu and Bassler, 1929). Celleporaria aperta was first found on the Israeli coast and considered as a Lessepsian migrant (Powell, 1969a). Agius et al. (1977) reported this species and $C$. pilaefera on the fouling cages of an oyster farm on Malta Island and suggested that they were introduced there via shipping. A total of 6 Celleporaria species [C. labelligera Harmer, 1957, C. vermiformis (Waters, 1909), C. columnaris (Busk, 1881), C. trispiculata d'Hondt, 1988, C. bicornis (Canu and Bassler, 1923) and C.pigmentaria (Waters, 1909)] were reported from the Red Sea (Powell, 1969a; 1969b; d'Hondt, 1988). The species belonging to this genus show a strong positive response to free space and are highly opportunistic and invasive (Dunstan and Johnson, 2004). Thus, they have favourable attributes to colonise new habitats. Celleporaria brunnea, which was known to inhabit tropical and temperate (warm and cool temperate) waters (Soule and Soule, 1964), was recorded for the first time in the Mediterranean Basin.

In the genus Celleporaria, the main morphological characters used in systematics are the shape of aperture, size, and the position and type of avicularia. In the Aegean specimens of $C$. brunnea, dark brown operculum and sclerites of mandibles in both oral and interzooidal avicularia were noted. In these specimens, the aperture was rounded distally but a distinct notch was not observed in the proximal part, as described by Soule (1961), Soule and Soule (1964) and Soule et al. (1997). The proximal border of apertures of our specimens was concave and arcshaped, with lateral condyles. The mandible of large interzooidal avicularia on the Pacific specimens had a spade-shaped brown reinforced sclerite in the midline (Soule and Soule, 1964). However, the mandible of interzooidal avicularia of our specimens had a spade-like sclerite with a short handle, as observed on the specimens collected from the coasts of Ecuador and Galapagos (Osburn, 1952; Hastings, 1929).

\section{ACKNOWLEDGMENTS}

I am much indebted to Jean-Georges Harmelin (France) for his constructive comments on the manuscript and for the photos taken by him with SEM. The study was carried out within the framework of the project "Seasonal dynamics of zoobenthos distributed in and around Alsancak Harbor (Izmir Bay, Turkey) and impacts of probable exotic species introduced by ships on the ecosystem-Project no. 03 SÜF 005”. 


\section{REFERENCES}

Agius, C., P.J. Schembri and V. Jaccarini. - 1977. A preliminary report on organisms fouling oyster cultures in Malta (Central Mediterranean). Mem. Biol. Mar. Oceanogr., 7: 51-59.

Ambrogi-Occhipinti, A. and D. Savini. - 2003. Biological invasions as a component of global change in stressed marina ecosystems. Mar. Pollut. Bull., 46: 542-551.

Bitar, G. and S.K. Bitar. - 2001. Nouvelles données sur la faune et la flore benthiques de la côte Libanaise. Migration Lessepsienne. Thalassia Salentina, 25: 71-73.

Brood, K. - 1980. Note on cyclostomatous bryozoans from Eilat, Israel. Zool. Scr., 9: 139-140.

Byers, J.E. - 2002. Impact of non-indigenous species on natives enhanced by anthropogenic alteration of selection regimes. Oikos 97(3): 449-457.

Carlton, C.T. - 1985. Transoceanic and interoceanic dispersal of coastal marine organisms: The biology of ballast water. Oceanogr. Mar. Biol. Annu. Rev., 23: 313-371.

Carlton, J.T. - 1989. Man's role in changing the face of the ocean: Biological invasions and implications for conservation of nearshore environment. Conserv. Biol., 3(3): 265-273.

Cognetti, G. and F. Maltagliati. - 2000. Biodiversity and adaptive mechanisms in brackish water fauna. Mar. Pollut. Bull., 40(1): 7-14

Cranfield, H.J., D.P. Gordon, R.C. Willan, B.A. Marshall, C.N Battershill, M.P Francis, W.A. Nelson, C.J. Glasby, and G.B. Read. - 1998. Adventive marine species in New Zealand, NIWA Tech. Rep., 34: 48 pp.

Dunstan, P.K. and C.R. Johnson. - 2004. Invasion rates increase with species richness in a marine epibenthic community by two mechanisms. Oecologia, 138: 285-292.

Galil, B.S. - 2000. A sea under siege-alien species in the Mediterranean. Biol. Invasions, 2: 177-186.

Galil, B.S. and A. Zenetos. - 2002. A sea change - Exotics in the Eastern Mediterranean Sea. In: E. Leppakoski, S. Gollasch and S. Olenin (eds.), Invasive Aquatic Species in Europe. Distribution, Impacts and Management, pp. 325-336. Kluwer Academic Publishers, Dordrecht.

Godwin, S.L. - 2003. Hull fouling of maritime vessels as a pathway for marine species invasion to the Hawaiian Islands. Biofouling, 19: $123-131$.

Gollasch, S. - 2002. The importance of ship hull fouling as a vector of species introductions in to the North Sea. Biofouling, 18(2): 105-121

Hastings, A.B. - 1929. Cheilostomatous Polyzoa from the vicinity of the Panama Canal collected by Dr. C. Crossland on the cruise of the S.Y. 'St. George', Proc. Zool. Soc. Lond., 47: 697-740.

Hondt J.-L. d'. - 1988. Bryozoans from the coast of Israel. Boll. Zool., 3: 191-203.

Kocak, F., Z. Ergen and M.E. Çınar. - 1999. Fouling organisms and their developments in a polluted and unpolluted marina in the Aegean Sea (Turkey). Ophelia, 50(1): 1-20.

Kocak, F., A. Balduzzi and H.A. Benli. - 2002. Epiphytic bryozoan community of Posidonia oceanica (L.) Delile meadow in the northern Cyprus (Eastern Mediterranean). Indian J. Mar. Sci., 3(3): 235-238.
Leppäkoski, E.J. - 2000. Introduced species-Resource or threat in brackish-water seas? Examples from the Baltic and the Black Sea. EMECS '90, 23: 219-223.

Leppäkoski, E.J. and S. Olenin. - 2000. Non-native species and rates of spread: lessons from the brackish Baltic Sea. Biol. Invasions, 2: 151-163.

Lewis, N.P., M.J. Riddle and C.L Hewitt - 2004. Management of exogenous threats to Antarctica and the sub-Antarctic Islands: balancing risks from TBT and non-indigenous marine organisms. Mar. Pollut. Bull., 49: 999-1005.

McMahon, F.R. - 2002. Evolutionary and physiological adaptations of aquatic invasive animals: $r$ selection versus resistance. Can . J. Fish. Aquat. Sci., 59: 1235-1244.

Minchin, D. and S. Gollasch. - 2003. Fouling and ships hulls: how changing circumstances and spawning events may result in the spread of exotic species. Biofouling, 19: 111-122.

Osburn, R.C. - 1952. Bryozoans of the Pacific coast of America, 2. Cheilostomata Ascophora. Allan Hancock Pacific Expeditions, 14, California Press, California.

Paavola, M., S. Olenin and E. Leppäkoski. - 2005. Are invasive species most successful in habitats of low native species richness across European brackish water seas? Est. Coast. Shelf. Sci., 64: 738-750.

Polard, D.A. and R.L. Pethebridge. - 2002. Report on Port Kembla introduced marine pest species survey. NSW Fisheries Final Report Series, 41: 1-85

Por, F.D. - 1971. One hundred years of Suez Canal-A century of Lessepsian migration: Retrospect and viewpoints. Syst. Zool., 20: $138-159$

Powell, N.A. - 1969a. Indo-Pacific bryozoans new to the Mediterranean coast of Israel. Isr. J. Zool., 18: 157-168.

Powell, N.A. - 1969 b. A checklist of Indo-Pacific bryozoans in the Red Sea. Isr. J. Zool., 18: 357-362.

Streftaris, N., A. Zenetos and E. Papathanassiou. - 2005. Globalization in marine ecosystems: The story of non-indigenous marine species across European Seas. Oceanogr. Mar. Biol., Annu. Rev., 43: 419-453.

Soule, J.D. - 1961. Results of the Puritan-American Museum of Natural History Expedition to Western Mexico, 13. Ascophoran Cheilostomata (Bryozoans) of the Gulf of California. Am. Mus. Novit., 2053: 1-65.

Soule, D.F. and J.D. Soule. - 1964. The Ectoprocta (Bryozoa) of Scammon's Lagoon, Baja California, Mexico. Am. Mus. Novit., 2199: 1-56.

Soule, D.F., J.D. Soule and H.W. Chaney. - 1997. Taxonomic atlas of the benthic fauna of the Santa Maria Basin and the Western Santa Barbara Channel, The Bryozoans, 13. Santa Barbara Museum of Natural History, California.

Unsal, I and J.-L d'Hondt. - 1978-1979. Contribution a la connaissance des bryozoaires marins de Turquie (Eurystomata et Cyclostomata). Vie Milieu, 28-29(4): 613-634.

Zibrowius, H. - 1991. Ongoing modification of the Mediterranean marine fauna and flora by the establishment of exotic species. Mésogée, 51: 83-107.

Scient. ed.: J. Garrabou.

Received April 25, 2006. Accepted December 5, 2006.

Published online March 1,2007. 
